\title{
Seminário Internacional José Mattoso
}

Revisitando a interdisciplinaridade: alimentação, doença e migrações, organizado pelo Instituto de Estudos Medievais, Lisboa, NOVA FCSH, 27 de Junho de 2019

\section{Paulo Catarino Lopes}

\section{(2penEdition}

\section{Journals}

Edição electrónica

URL: http://journals.openedition.org/medievalista/2936

DOI: $10.4000 /$ medievalista.2936

ISSN: 1646-740X

\section{Editora}

Instituto de Estudos Medievais - FCSH-UNL

\section{Refêrencia eletrónica}

Paulo Catarino Lopes, "Seminário Internacional José Mattoso », Medievalista [Online], 27 | 2020, posto online no dia 01 janeiro 2020, consultado o 23 setembro 2020. URL : http://journals.openedition.org/ medievalista/2936; DOI : https://doi.org/10.4000/medievalista.2936

Mediavalista está licenciado com uma Licença Creative Commons - Atribuição-NãoComercial 4.0 Internacional. 
Título / Title (Português e Inglês): Seminário Internacional José Mattoso - Revisitando a interdisciplinaridade: alimentação, doença e migraçães, organizado pelo Instituto de Estudos Medievais, Lisboa, NOVA FCSH, 27 de Junho de 2019

Autor(es) / Author(s): Paulo Catarino Lopes

Afiliação institucional / Institutional affiliation (Universidade, Faculdade, Departamento ou Unidade de Investigação / University, Faculty, Department or Research Centre): Instituto de Estudos Medievais, Faculdade de Ciências Sociais e Humanas, Universidade Nova de Lisboa

Código postal / Postcode; Cidade / City; País / Country: 1069-061 Lisboa, Portugal ORCID: http://orcid.org/0000-0002-8543-1111

Email Institucional / Institutional email: peclopes@gmail.com

Fonte: Medievalista [Em linha]. Direc. Bernardo Vasconcelos e Sousa. Lisboa: IEM.

Disponível

em:

http://www2.fcsh.unl.pt/iem/medievalista/MEDIEVALISTA27/lopes27V3.html ISSN: 1646-740X

Data recepção do artigo / Received for publication: 11 de setembro de 2019 


\section{Seminário Internacional José Mattoso “Revisitando a interdisciplinaridade: alimentação, doença e migrações", organizado pelo Instituto de Estudos Medievais, Lisboa, NOVA FCSH, 27 de Junho de 2019}

\section{Paulo Catarino Lopes}

Criados em 2004 por Luís Krus, os Seminários José Mattoso pretendem desde o seu início constituir um espaço privilegiado de reflexão crítica, debate científico e diálogo produtivo e inovador, valorizando a problematização historiográfica em torno de questões e conceitos propostos por esse historiador. Parecera-lhe ser esta a forma mais estimulante e fecunda de homenagear a figura incontornável de José Mattoso e a sua obra.

Depois de um interregno de alguns anos, o Instituto de Estudos Medievais decidiu reactivar este fórum de debate, que inseriu nas suas actividades bienais. Assim, em 2014, o Seminário Mattoso dedicou-se à importância do diálogo interdisciplinar na invenção de uma outra visão da Idade Média. Em 2016 discutiu-se o impacto, a operacionalidade e a actualidade do binómio "Oposição/Composição" tal como proposto por José Mattoso na sua obra seminal Identificação de um País. Ensaio sobre as origens de Portugal. Este ano pretendeu-se regressar à interdisciplinaridade e ao diálogo entre áreas científicas que normalmente não comunicam umas com as outras, abordando pela voz de alguns dos mais reputados e inovadores especialistas internacionais e portugueses as problemáticas da Doença, Alimentação e Migração.

$\mathrm{Na}$ apresentação inaugural do encontro, a investigadora Monica Green da Arizona State University falou das suas pesquisas de ponta sobre o tema da Peste Negra como História Global ("The Black Death as Global History”). Especialista em história médica da Europa 
medieval e na história global de doenças infecciosas, esta professora norte-americana comentou como a nossa percepção da Peste Negra, a pandemia de peste que devastou a Europa, o Médio Oriente e o Norte da África entre 1346 e 1353, sofreu nos últimos 15 anos uma acentuada transformação como resultado de novos e profundos desenvolvimentos no campo da genética. Com efeito, historiadores e arqueólogos aprenderam nos últimos anos a incorporar as descobertas da genética em novas narrativas críticas, que revelam como aquela que é considerada a maior das pandemias foi, na realidade, mais impactante e generalizada do que alguma vez imaginámos. O resultado é que os estudos históricos sobre este fenómeno que marcou profundamente o percurso da Humanidade devem agora incluir, em termos da especialidade, não apenas $o$ Mediterrâneo e a Europa, mas também a Ásia Central, a China e grande parte da África Subsaariana.

Em seguida, Kirsten Bos, especialista em DNA antigo e doenças infecciosas, apresentou uma comunicação intitulada "Ancient pathogen genomics of Medieval plagues". Actual coordenadora do grupo de investigação em paleopatologia molecular no Instituto Max Planck para a Ciência da História Humana em Jena, na Alemanha, esta antropóloga física partilhou como as técnicas de recuperação de DNA antigo permitem hoje sequenciar DNA suficiente de tecidos arqueológicos preservados, por forma a que se possa reconstruir computacionalmente os genomas de patógenos antigos. A questão está em que a partir daqui é possível identificar doenças de há centenas de anos e determinar as suas relações genéticas com formas modernas. Kirsten Bos, com efeito, utilizou já essas técnicas na investigação que conduz sobre a Peste Negra e outras infecções causadas pela bactéria Yersinia pestis (hanseníase, cólera, tuberculose e, mais recentemente, febre paratifóide).

A terceira apresentação deste encontro científico foi protagonizada por Iona McCleery do Institute for Medieval Studies da Universidade de Leeds (IMS - Leeds University), que abordou o sempre complexo tema da dieta medieval com a comunicação "The "healthy' medieval diet: interdisciplinary perspectives". Especializada em medicina e alimentação medieval (assim como no estudo quer do Portugal medievo, quer dos milagres e Culto dos Santos), esta investigadora centrou a sua intervenção numa interrogação fundamental: “o que é uma dieta medieval saudável?”. Partindo da relação entre as palavras “dieta” e 
"saudável", ela demonstrou como o que entendemos por "saudável" é frequentemente considerado um dado adquirido, acabando por funcionar como uma premissa anacrónica. $\mathrm{Na}$ sua perspectiva existem muitas maneiras de investigar a dieta medieval, devendo-se, no entanto, dar primazia à questão de quais os padrões de saúde que consideramos pertinentes: os nossos, portanto actuais, ou os do contexto epocal em exame? Fazendo recurso de várias disciplinas e campos de estudo, pois, a comida é um tópico interdisciplinar por excelência, que exige vários conjuntos de dados e escalas de análise, o seu propósito consistiu, enfim, em problematizar a ideia de que sabemos o que significa "saudável" ao olhar para a comida medieval.

Depois, numa perspectiva zooarqueológica, Cleia Detry (UNIARQ - Faculdade de Letras da Universidade de Lisboa) chamou a atenção para a problemática do "Consumo, melhoramento e introdução de animais durante o período medieval”. Esta especialista sublinhou na sua intervenção como durante o período medieval tiveram lugar profundas alterações culturais e económicas, que afectaram necessariamente o consumo e a gestão que as populações faziam dos animais. Dando como exemplos maiores os casos do porco, com a proibição do seu consumo pelos muçulmanos, da ovelha, do gado bovino e das espécies exóticas, introduzidas sobretudo a partir do Norte de África e da zona do Mediterrâneo, alterando para sempre ecossistemas locais e consumos, Cleia Detry demonstrou como a Zooarqueologia e a Osteometria têm contribuído para a compreensão do impacto das diferentes culturas no ecossistema da Península Ibérica, no consumo da carne e no melhoramento dos animais.

Finalmente, Sofia Tereso (CIAS - Faculdade de Letras da Universidade de Coimbra / IEM - NOVA FCSH) apresentou o projecto que se encontra a desenvolver numa comunicação intitulada "Que nos contam os ossos? Conhecer as populações altomedievais do NE transmontano através da bioarqueologia”. Esta investigadora salientou que conhecer as populações alto-medievais do NE transmontano, entre o Tua/Tuela e o Douro, através da bioarqueologia, assume-se como um estudo relevante no contexto arqueológico nacional, uma vez que não existe conhecimento suficiente sobre esta cronologia e região. Além disso, os restos ósseos exumados das cinco necrópoles em estudo são únicos num ambiente geológico que raramente permite a sua preservação. $O$ projecto em questão assume uma abordagem metodológica interdisciplinar, onde se 
conjugam a arqueologia, a antropologia, a química e a genética, em ordem a um conhecimento aprofundado das comunidades alto-medievais. Não só é abordado o modo como essas populações organizavam o seu espaço funerário, a arquitetura dos sepulcros e os rituais funerários adoptados, como também é caracterizado o seu estilo de vida, as patologias que deixaram marca nos ossos, os padrões ocupacionais, a dieta e a mobilidade ao longo da sua vida. Para além da vida e da morte das comunidades, este estudo permite igualmente abordar a distinção social no seio da comunidade e entre comunidades.

No final deste encontro científico ficou a consciência da importância e da necessidade cada vez mais premente de diálogo entre disciplinas para a construção do saber histórico sobre a Idade Média. Um diálogo cruzando as áreas da História de Arte, Literatura, História, Filosofia, Antropologia e Arqueologia com campos de estudo mais "técnicos" e durante largo tempo estranhos aos medievalistas como as ciências biológicas e químicas.

Inequívocas revelaram-se a pertinência e a utilidade futura do Seminário Internacional José Mattoso, enquanto espaço de debate entre perspectivas originais, sobre as diversas problemáticas e quadros conceptuais que compõem os estudos medievais. Uma realidade que logo à partida garante ao evento o estatuto de plataforma privilegiada de investigação, não somente para networking, mas também para a apresentação de metodologias inovadoras, assim como para a partilha de dados e de experiências entre os vários níveis de participantes. 


\section{COMO CITAR ESTE ARTIGO}

\section{Referência electrónica:}

LOPES, Paulo Catarino - "Seminário Internacional José Mattoso - Revisitando a interdisciplinaridade: alimentação, doença e migrações, organizado pelo Instituto de Estudos Medievais, Lisboa, NOVA FCSH, 27 de Junho de 2019”. Medievalista 27 (janeiro-junho 2020) [Em linha] [Consultado dd.mm.aaaa]. Disponível em http://www2.fcsh.unl.pt/iem/medievalista/MEDIEVALISTA27/ lopes27V3.html

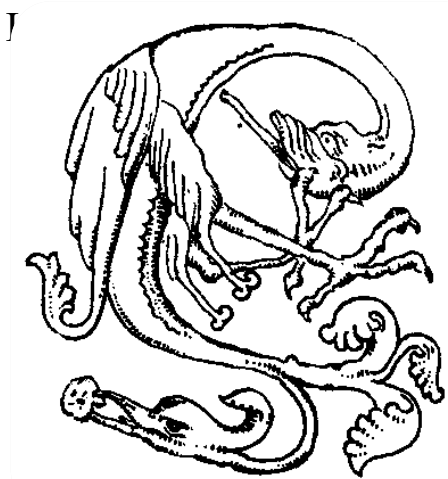

